\title{
The Effect of Stromal Vascular Fraction for Patients with Androgenetic Alopecia
}

\section{(1) Perihan Öztürk', (1) Mehmet Bekerecioğlu²}

${ }^{1}$ Kahramanmaras Sutcu Imam University Faculty of Medicine, Department of Dermatology, Kahramanmaras, Turkey 2Kahramanmaras Sutcu Imam University Faculty of Medicine, Department of Plastic Surgery, Kahramanmaras, Turkey

\section{ABSTRACT}

Background: Androgenetic alopecia (AGA) is a dermatological disease that can be seen in both men and women and can cause problems in one's self-perception. Stem cell is an increasingly popular treatment method in the treatment of various diseases in recent medicine. Stromal vascular fraction (SVF) is a specimen that contains high levels of stem cells and very easy to be obtained from fat. In our study, we investigated the effectiveness of SVF treatment in AGA patients.

Materials and Methods: Twenty patients were included in the study. Fourteen (70\%) of the patients were male and 6 (30\%) were female. The age of the patients was minumum-maximum 21-41 years. In the $3^{\text {rd }}$ month of the study, the hair density and increase in thickness of hair of patients were evaluated with both macroscopic and trichoscopic examination.

Results: An increase in both hair density and hair thickness was detected in the $3^{\text {rd }}$ month.

Conclusion: It was concluded that SVF is an effective and safe treatment option in AGA.

Keywords: Androgenetic alopecia, Stromal vascular fraction, Stem cell

\section{Introduction}

Androgenetic alopecia (AGA) is an androgen-dependent progressive disease that causes hair loss in women and men with genetic predisposition [1]. AGA is the most common type of alopecia and by the age of 60 , it affects 80 percent of men and 50 percent of women $[2,3]$. It is categorized as a nonscarring patterned form of alopecia and is characterized by bitemporal recession, a progressive loss of hair in the frontoparietal region in men, and a diffuse hair thinning with preservation of frontal hairline in women [2]. In women, it can be seen as female pattern hair loss and also it may seen with hyperandrogenemic hormone changes and findings $[4,5]$. It is believed that a high concentration of dihydrotestosterone against androgen-sensitive hair follicles lead to thinning of the dermal papillae and shortening of the anagen phase is the underlying mechanism [6,7]. Diagnosis of AGA is mostly made with a history and physical examination without any laboratory examination [4]. Current acknowledged treatment modalities concentrates on various mechanisms: androgenic effects on hair follicles are reduced by using 5a-reductase inhibitors, hair growth is stimulated by minoxidil, moving androgen in dependent hair to the affected scalp is done by hair transplantation $[8,9,10]$.

Stem cells differ from mature cells by some features they possess and have a very important potential in clinical applications. These features are the trophic effect they have, immune system modulation, heading to the injury site (homing) and tissue differentiation $[11,12]$. Stem cells show their trophic effect through 
their growth factors, cytokines, extracellular matrix elements, extracellular matrix proteases, hormones and lipid mediators in the region or micro-environment in that they are applied. In particular, vascular endothelial growth factor, hepatocyte growth factor and transforming growth factor-beta increase angiogenesis and wound healing, as well as stimulating new tissue formation and growth [13]. With the studies carried out in the early 2000s on the adipose tissue, it has been revealed that the human body is a very important source for stem cells [14]. Compared to bone marrow, which is the most important source of stem cells known to date, interest in adipose tissue and mesenchymal stem cells derived from adipose tissue [adipose-derived stem cells (ADSC)] has increased rapidly in recent years due to its easier access and potential to obtain more cells [15].

Stromal vascular fraction (SVF) is a heterogeneous cell cocktail that is obtained by the enzymatic destruction of surgically acquired fat tissue (either through excision or lipoaspiration), it is known to be rich in stem cells, containing preadipocyte, endothelial cells, hematopoietic serial cells, fibroblasts as well as ADSCs and pericides located around the vessels $[16,17]$.

Underlying inflammation is spotted in various degrees in many scarring and nonscarring forms of alopecia. In patients with AGA, mild perifollicular fibrosis and infiltrates are also detected [18]. By enhancing antioxidative and anti-inflammatory mechanisms, ADSCs can prevent further inflammation and potential damage to hair follicles. Their anti-inflammatory and immunomodulatory properties are reflected in their potential to prevent the maturation and production of cytokines and to disrupt the cytotoxic potential of natural killer cells and T lymphocytes [19].

When injected into an area that is affected by hair loss, adipose tissue may show an antiandrogen effect without causing systemic effects [20].

We planned to use both the anti-inflammatory and antiandrogenic effects of SVF and to work with the idea that cytokines released from SVF will correct neovascularization, an important pathological problem in AGA.

\section{Materials and Methods}

Twenty patients diagnosed with AGA between 2018 and 2020 were included in the study after obtaining their consent. Before the study started, approval was obtained from the Ethics Committee of Kahramanmaras Sutcu Imam University Faculty of Medicine with the number 236 .

Inclusion criteria for the study:

- Male and female patients with AGA,

- To be 15 years old or older,
- Active hair loss within last six months,

- Hamilton score 3 to 4 in male patients and Ludwig score 1-3 in female patients.

Exclusion criteria for the study:

- Patients with inflammation, infection, malignancy, allergic disease, autoimmune disease, pregnancy, and on current anticoagulant therapy,

- Patients on chemotherapy during the last 5 years.

- Having received oral, topical or intradermal hair loss treatment in the last 6 months,

For the svf preparation management, the following operations are carried out in order on a beautycell device from bitorend company.

- Patients are prepared for the procedure under local anesthesia. 50 $\mathrm{mL}$ of fat is taken from the belly area through liposuction method. The fat tissue aspirated by liposaction is transferred into $50 \mathrm{~mL}$ falcon tubes as $25 \mathrm{~mL}$ each and is completed with Ringer lactate/SF solution up to $50 \mathrm{~mL}$.

- It is centrifuged at $100 \mathrm{~g}$ for 3 minutes.

- The red blood cell part of the centrifuged fat tissue is separated from the bottom of the falcon tube with the help of a $10 \mathrm{~mL}$ pipette.

- Adipose tissue purification is performed.

- $25 \mathrm{~mL}$ of adipose tissue, which has been purified, is completed with $25 \mathrm{~mL}$ of Ringer's lactate/SF solution to $50 \mathrm{~mL}$.

- $0.5 \mathrm{~mL}$ enzyme solution is added.

- It is taken to the incubator which has a temperature of $37^{\circ} \mathrm{C}$ and is incubated for 30 minutes at $200 \mathrm{rpm}$ shaking speed.

- After incubation, adipose tissue is centrifuged at $800 \mathrm{~g}$ for 5 minutes.

- After centrifugation, the fat tissue on the top is discarded with a $25 \mathrm{~mL}$ pipette.

- The concentration in the Falcon tube is discarded by pulling downwards with a pipette until it remains $5 \mathrm{~mL}$ at the bottom.

- The $5 \mathrm{~mL}$ cell suspension isolated from adipose tissue is completed to $50 \mathrm{~mL}$ with Ringer lactate/SF solution.

- It is centrifuged at $300 \mathrm{~g}$ for 3 minutes.

- After centrifugation, the top part is discarded with a pipette, leaving $5 \mathrm{~mL}$ of liquid in the bottom.

- The enzyme is removed from the cell suspension, by repeating this washing process 3 or 4 times.

- The cell suspension, which has been washed, is passed through a filter (cell strainer $100 \mu \mathrm{m}$ ) placed in a sterile falcon tube.

- SVF cell suspension is obtained at the bottom of the falcon tube.

$5 \mathrm{~mL}$ SVF was applied to the scalp of the patient with $30 \mathrm{~g}-4 \mathrm{~mm}$ 
needle by intradermal injection technique. After a total of 25 injections of $0.2 \mathrm{~mL}$ in each area, the process was completed by applying $2 \mathrm{~mm}$ dermapen. The most important point to be considered here is that the obtained SVF was used without waiting for the procedure. The procedure was applied for once. Patients were able to return to work after the procedure. All patients were told that they should not wash their hair for 24 hours, and avoid some works such as 3 hours of heavy exercise, and do not have a sun bath for 1 week. Before the procedure, macroscopic images of all patients were recorded and bitemporal and vertex photographs were taken with "fotofinder medicam 800 hd" trichoscope camera.

\section{Statistical Analysis}

After 12 weeks, patients were called for control and changes in the same regions were re-evaluated with visual analog scale and changes in the data which are entered in SPSS 23 were recorded as \%.

\section{Results}

Of the patients included in the study, 14 (70\%) were male and $6(30 \%)$ were female. The age of the patients was minimum-maximum 2141 years. Two (14.28\%) of the male patients were stage 1, 4 (28.6\%) were stage 2, $6(42.9 \%)$ were stage 3 , and $2(14.28 \%)$ were stage 4 . Two (33.3\%) of the female patients were evaluated as stage 1, 2 (33.3\%) as stage 2 , and $2(33.3 \%)$ as stage 3 . When looking at the density of hair in the temporo-parietal region in the $3^{\text {rd }}$ month in male patients, $25 \%$ of the patients did not change, while $25 \%$ increased by $10 \%$ and $50 \%$ increased by $20 \%$. In vertex, there was a $10 \%$ increase in hair density in $75 \%$ of patients, while there was a $20 \%$ increase in $25 \%$ of patients. In terms of hair thickness: In the temporo-parietal region, in all patients, the hair thickness has increased by $25 \%$. In vertex, there was no change in $50 \%$, while in $25 \%$, hair thickness increased by $10 \%$ and in the remaining $25 \%$ it is increased by $30 \%$ (Figures 1, 2).

In female patients, an increase of $10 \%$ was observed in $50 \%$ of the patients, while an increase of $20 \%$ was observed in $50 \%$ of the patients. In vertex, only $10 \%$ increase was observed in all patients. There was no change in hair thickness.

\section{Discussion}

In our study, it was concluded that the application of SVF on a single session in patients with AGA, which is difficult to treat, provides a significant increase in the number and thickness of hair, especially in the bitemporal region.

Adipose tissue has an important place in both tissue engineering and regenerative medicine applications as a biological active complex. Adipose tissue can be used either directly as SVF or as stem cell separated from SVF [21]. In our study, we used SVF, which contains stem cell, directly. SVF is considered to be a very useful method as it becomes usable within approximately 2 hours after it is obtained from adipose tissue. There are very few studies evaluating the outcome of SVF treatment for hair loss. The studies were mostly done with cultured adipose tissue stem cell and blood derived stem cell [22,23]. Anderi et al. [24] reported that treatment with SVF is an effective and safe method in 20 patients with alopecia areata. Cohen et al. [25] reported in 2010 that the fat enriched with SVF was injected into the scalp of a woman with alopecia and it resulted in a "significant improvement in hair growth" after nine months of follow-up. PerezMeza et al. [26] injected SVF-enriched autologous fat into five patients who are aged 18 to 55 years in another study. The liposuction and the application of the SVF solution were done on the same day and patients were followed up with for up to 24 weeks postoperatively.
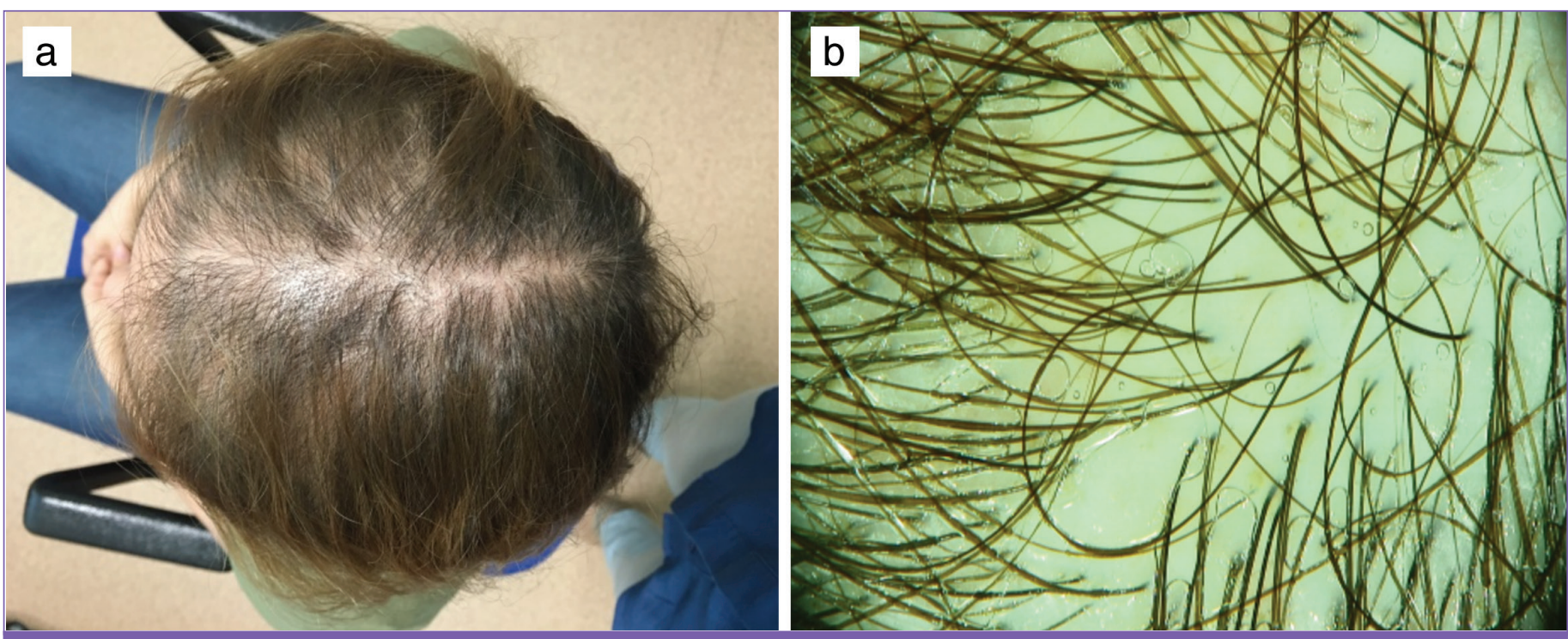

Figure 1. a) Pretreatment, b) pretreatment 

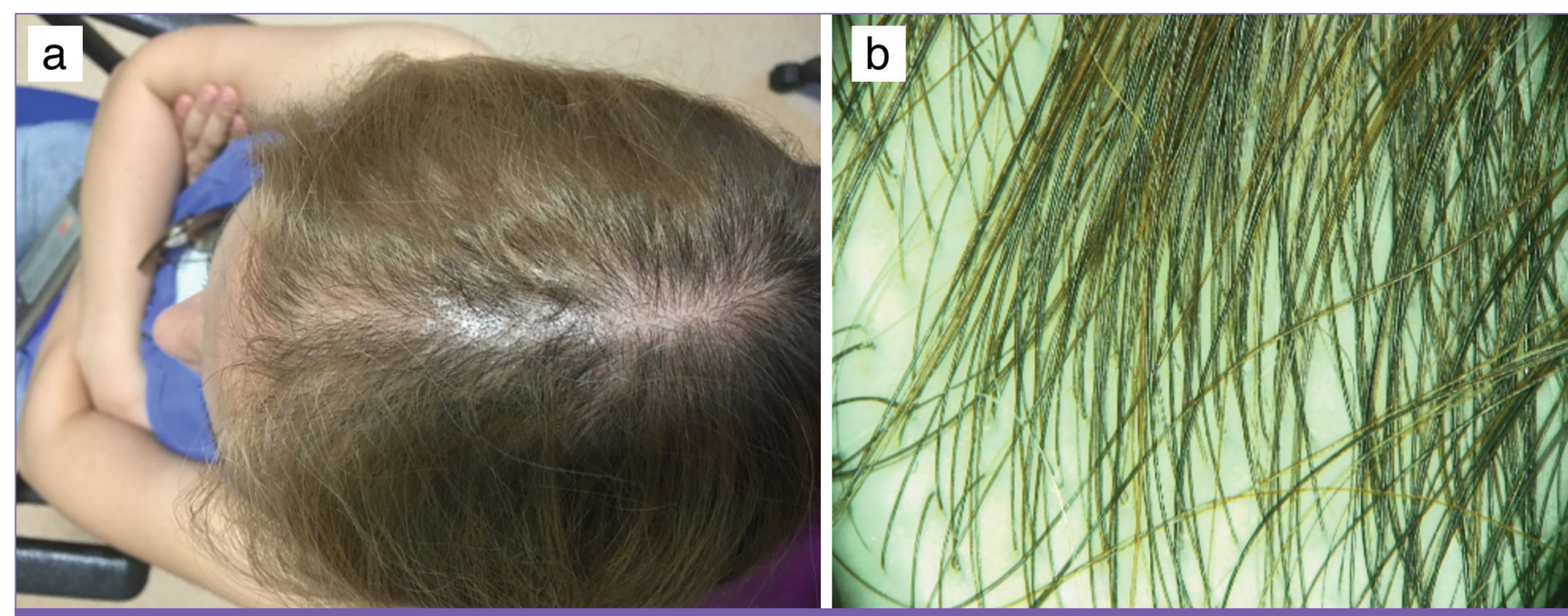

Figure 2. a) Posttreatment, b) posttreatment

On average, 23\% increase in hair count and 24.2\% increase in hair thickness were reported with an increase of $93 \%$ in the amount of anagen hairs and decrease of 35\% in the amount of telogen hairs. Aronowitz et al. [27] showed a significant 14\% increase in hair count at six months after the autologous fat enriched with SVF was applied to the scalp of eight men and a woman with hair loss. In addition, the number of anagen phase hair has been increased by 34 percent. In our study, unlike other studies, the dermapen process was added to increase the regional blood supply and through the increased blood supply it was aimed to make growth factors that provide wound healing come to the area that was treated. Thus, additional contribution was made to the paracrine effect, antiandrogen effect and anti-inflammatory effect of SVF.

\section{Study Limitations}

The low number of patients is the limitation of our study.

\section{Conclusion}

As a result, SVF along with dermapen administration can be an effective and safe treatment method in AGA.

\section{Ethics}

Ethics Committee Approval: It was approved by the Ethics Committee of Kahramanmaras Sutcu Imam University Faculty of Medicine (protocol number: 236).

Informed Consent: Consent form was filled out by all participants.

Peer-review: Internally peer-reviewed.

\section{Authorship Contributions}

Surgical and Medical Practices: P.Ö., M.B., Concept: P.Ö., M.B., Design: P.Ö., M.B., Data Collection or Processing: P.Ö., M.B., Analysis or Interpretation: P.Ö., Literature Search: P.Ö., Writing: P.Ö.
Conflict of Interest: No conflict of interest was declared by the authors.

Financial Disclosure: This article supported by Kahramanmaras Sutcu Imam University Scientific Research Projects with number 2018/4-28M

\section{References}

1. Kutlubay Z, Bağlam S, Engin B, Serdaroğlu S. Erkeklerde Androgenetik Alopesi. Turkderm 2014;48:36-39.

2. Piraccini BM, Alessandrini A. Androgenetic alopecia. G Ital Dermatol Venereol 2014;149:15-24.

3. Varothai S, Bergfeld WF. Androgenetic alopecia: an evidence-based treatment update. Am J Clin Dermatol 2014;15:217-230.

4. Unal I. Female pattern hair loss. Turkderm 2014;48:(Suppl 1)31-35.

5. Olsen EA, Messenger AG, Shapiro J, Bergfeld WF, Hordinsky MK, Roberts JL, Stough D, Washenik K, Whiting DA. Evaluation and treatment of male and female pattern hair loss. J Am Acad Dermatol 2005;52:301-311.

6. Ramos PM, Miot HA. Female pattern hair loss: a clinical and pathophysiological review. An Bras Dermatol 2015;90:529-543.

7. Ellis JA, Sinclair R, Harrap SB. Androgenetic alopecia: pathogenesis and potential for therapy. Expert Rev Mol Med 2002;4:1-11.

8. Sendur N, Karaman GC. Androgenetic alopecia. ADU Tıp Fakültesi Dergisi 2000;1:39-46.

9. Leavitt ML. Women and Hair Loss. Atlanta, USA: Beautiful Media Publisher; 2004.

10. Stefanis AJ, Groh T, Arenbergerova M, Arenberger P, Bauer PO. Stromal Vascular Fraction and its Role in the Management of Alopecia: A Review J Clin Aesthet Dermatol 2019;12:35-44.

11. Kapur SK, Katz AJ. Review of the adipose derived stem cell secretome. Biochimie 2013;95:2222-2228.

12. Salgado AJ, Reis RL, Sousa NJ, Gimble JM. Adipose tissue derived stem cells secretome: soluble factors and their roles in regenerative medicine. Curr Stem Cell Res Ther 2010;5:103-110. 
13. Aksu AE, Çalıs M. Adipose-derived mesenchymal stem cells and the concept of stromal vascular fraction. Turkiye Klinikleri J Plast Surg-Special Topics 2015;4:19-26

14. Zuk PA, Zhu M, Mizuno H, Huang J, Futrell JW, Katz AJ, Benhaim P, Lorenz HP, Hedrick MH. Multilineage cells from human adipose tissue: implications for cellbased therapies. Tissue Eng 2001;7:21-28.

15. Mizuno H, Tobita M, Uysal AC. Concise review: Adipose-derived stem cells as a novel tool for future regenerative medicine. Stem Cells 2012;30:804-810.

16. Kokai LE, Marra K, Rubin JP. Adipose stem cells: biology and clinical applications for tissue repair and regeneration. Transl Res 2014;63:399-408.

17. Alharbi Z, Oplander C, Almakadi S, Fritz A, Vogt M, Pallua N. Conventional vs. micro-fat harvesting: how fat harvesting technique affects tissue-engineering approaches using adipose tissue-derived stem/stromal cells. J Plast Reconstr Aesthet Surg 2013;66:1271-1278.

18. Shin $\mathrm{H}$, Won $\mathrm{CH}$, Chung WK, Park BS. Up-to-date clinical trials of hair regeneration using conditioned media of adipose-derived stem cells in male and female pattern hair loss. Curr Stem Cell Res Ther 2017;12:524-530.

19. Zhao S, Wehner R, Bornhäuser M, Wassmuth R, Bachmann M, Schmitz M. Immunomodulatory properties of mesenchymal stromal cells and their therapeutic consequences for immunemediated disorders. Stem Cells Dev 2010;19:607-614.

20. Epstein GK, Epstein JS. Mesenchymal stem cells and stromal vascular fraction for hair loss: Current status. Facial Plast Surg Clin N Am 2018:6:503-511.
21. Butt G, Hussain I, Jawad Ahmad F, Choudhery MS. Stromal vascular fractionenriched platelet-rich plasma therapy reverses the effects of androgenetic alopecia. J Cosmet Dermatol 2020;19:1078-1085.

22. Fukuoka $\mathrm{H}$, Suga $\mathrm{H}$. Hair regeneration treatment using adipose-derived stem cell conditioned medium: follow-up with trichograms. Eplasty 2015;15:e10.

23. Shin H, Ryu HH, Kwon O, Park BS, Jo SJ. Clinical use of conditioned media of adipose tissue-derived stem cells in female pattern hair loss: a retrospective case series study. Int J Dermatol 2015;54:730-735.

24. Anderi R, Nehman R, Makdissy N, Azar A, Rizk F, Hamade A. Cellular therapy with human autologous adipose-derived adult cells of stromal vascular fraction for alopecia areata. Stem Cell Res Ther 2018;9:141.

25. Cohen SR, Hewett S, Ross L, Delaunay F, Goodacre A, Ramos C, Leong T. Regenerative cells for facial surgery: biofiling and biocontouring. Aesthet Surg J 2017;37(Suppl 3):S16-S32.

26. Perez-Meza D, Ziering C, Sforza M, Krishnan G, Ball E, Daniels E. Hair follicle growth by stromal vascular fractionenhanced adipose transplantation in baldness. Stem Cells Cloning 2017;10:1-10.

27. Aronowitz JA, Lockhart RA, Birnbaum ZE, Hakakian CS, Daniels E, Washenik K. Stromal vascular fraction enhanced adipose transplantation in hair loss early experience \& active phase II FDA investigation. Plast Reconstr Surg Glob Open 2016;4(Suppl 9):50. 